\title{
FEATURES OF ISOTHERMAL MULTICOMPONENT MIXING OF GAS MIXTURES CONTAINING METHANES AT CONVECTIVE INSTABILITY
}

\author{
Kossov V. N. ${ }^{1,2}$, Mukamedenkyzy $V .{ }^{2}$, Zhussanbayeva A. ${ }^{l}$ \\ ${ }^{1}$ Abai Kazakh National Pedagogical University, Almaty, Kazakhstan \\ ${ }^{2}$ Institute of Experimental and Theoretical Physics, Almaty, Kazakhstan
}

\begin{abstract}
The features of the change in the regimes "diffusion-gravitational concentration convection" in isothermal ternary gas mixtures have been studied experimentally and numerically. It is shown that, at a certain pressure, due to the difference in the diffusion coefficients of the components, an instability of mechanical equilibrium arises, leading to the appearance of structured convective formations. Calculation results are compared with experimental data on the location of the instability boundaries in the studied gas mixtures. Intensity of convective mixing is also influenced by the content of the component with the highest molecular weight in the initial mixture. In terms of Rayleigh numbers, a boundary relation is obtained that determines the regime change.

The solution of the problem of multicomponent mixing in a cylindrical vertical channel of finite height with solid and impermeable boundaries for the substance made it possible to determine the concentration distribution along the length.
\end{abstract}

Keywords: convection, diffusion, instability, concentration, synergistic effect, mechanical equilibrium.

\author{
Аннотация \\ Косов В.Н. ${ }^{1,2}$, Мукамеденқыьзы В. ${ }^{2}$, Жусанбаева А. ${ }^{1}$ \\ ${ }^{1}$ Казахский национальный педагогический университет им.Абая, Алматы, Казахстан \\ ${ }^{2}$ Институт экспериментальной и теоретической физики, Алматы, Казахстан
ОСОБЕННОСТИ ИЗОТЕРМИЧЕСКОГО МНОГОКОМПОНЕНТНОГО СМЕШЕНИЯ ГАЗОВЫХ СМЕСЕЙ СОДЕРЖАЩИХ МЕТАН ПРИ КОНВЕКТИВНОЙ НЕУСТОЙЧИВОСТИ

Экспериментально и численным образом изучены особенности смены режимов «диффузия- гравитационная концентрационная конвекция» в изотермических тройных газовых смесях. Показано, что при определенном давлении за счет различия в коэффициентах диффузии компонентов возникает неустойчивость механического равновесия, приводящая к возникновению структурированных конвективных формирований. Результаты расчетов сравниваются с опытными данными по расположению границ неустойчивости в исследуемых газовых смесях. На интенсивность конвективного смешения также оказывает влияние содержание компонента с наибольшим молекулярным весом в исходной смеси. В терминах чисел Рэлея получено граничное соотношение, определяющее смену режимов.

Решение задачи о многокомпонентном смешении в цилиндрическом вертикальном канале конечной высоты с твердыми и непроницаемыми для вещества границами позволило определить распределение концентрации по длине.

Ключевые слова: конвекция, диффузия, неустойчивость, концентрация, синергетический эффект, механическое равновесие.

\section{Аңุдатпа \\ В.Н. Косов ${ }^{1,2}$, В. Мукамеденқызыз ${ }^{2}$, А. Жусанбаева ${ }^{1}$ \\ ${ }^{1}$ Абай атындавы Қазақ ұлттық педагогикалық университеті, Алматы құ., Казахстан \\ ${ }^{2}$ Эксперименттік және теориялық институті, Алматы қ., Қазақстан \\ КОНВЕКТИВТІ ТҰРАҚСЫЗДЫҚ КЕЗІНДЕ МЕТАНЫ БАР ГАЗ ҚОСПАЛАРЫН ИЗОТЕРМИЯЛЫК КӨП КОМПОНЕНТТІ АРАЛАСТЫРУДАҒЫ ЕРЕКШЕЛІКТЕРІ}

Изотермиялық үш компонентті газ қоспаларында «диффузиялық-гравитациялық концентрация конвекциясы» режимдерінің өзгеру ерекшеліктері тәжірибелік және сандық тұрғыдан зерттелген. Белгілі бір қысым кезінде компоненттердің диффузия коэффициенттерінің айырмашылығына байланысты, құрылымдық конвективті түзілімдердің пайда болуына әкелетін механикалық тепе-теңдіктің тұрақсыздығы пайда болатыны көрсетілген. Есептеу нәтижелері зерттелетін газ қоспаларындағы тұрақсыздық шекараларының орналасуы бойынша тәжірибелік деректермен салыстырылған. Конвективті араластырудың қарқындылығына бастапқы қоспадағы ең жоғары молекулалық салмағы бар компоненттің құрамы да әсер етеді. Рэлей сандарының терминінде ауысымды режимдерін де анықтайтын шекаралық қатынас алынды. 
Концентрацияның ұзындығы бойынша таралуын анықтауға мүмкіндік беру үшін соңғы биіктіктің цилиндрлік тік каналында қатты және зат өткізбейтін шекаралары бар көп компонентті араластыру процессі де іске асты.

Түйін сөздер: конвекция, диффузия, тұрақсыздық, концентрация, синергетикалық эффект, механикалық тұрақтылық.

In multicomponent gas mixtures, there is a wide variety of mixing regimes [1]. The experiments were carried out on a device in which two flasks were connected by a vertical channel. In the work [2] shows high-quality shadow images of diffusion instability in the flasks of the diffusion apparatus. Experiments on the study of multicomponent mixing in gases at elevated pressure [3, 5], diffusion of a mixture of solution vapors into an inert gas [4] registered convective flows. In its turn, this convective flows leading to a synergistic effect. The synergistic effect associated with a significant increase in the mixing rate of the system components. Features which are observed in [3-5], during change of the "diffusion - convection" regimes is the fact, that it is realized not under traditional conditions corresponding to the thermal problems of Rayleigh [6] and Rayleigh-Taylor [7], arises under the condition that the density of the mixture decreases with height. In this work, researching the mechanism of the "diffusion - convection" transition in gas mixtures containing methane, which is important for the problems of combined heat and mass transfer of multicomponent systems containing hydrocarbon components. This feature arises at the initial hydrostatic stable stratification, which implies a decrease of the density of the mixture with height.

In this work presents experimental data on the study of boundaries of change in kinetic regimes. Analytical results on the research of ternary gas mixtures for convective stability in vertical channels are showed. Comparison is made between experiments and theoretical calculations.

In experiments for research were chose systems $0,65 \mathrm{CH}_{4}(1)+0,35 \mathrm{Ar}(2)-\mathrm{N}_{2}$ (3) and $0,5538 \mathrm{H}_{2}(1)+0,4462 \mathrm{~N}_{2}(2)-\mathrm{CH}_{4}(3)$ The experimental data for systems $\mathrm{CH}_{4}+\mathrm{Ar}-\mathrm{N}_{2}$ and $\mathrm{H}_{2}+\mathrm{N}_{2}-\mathrm{CH}_{4}$ are shown in figure 1 as the dependence of the dimensionless parameter $\alpha$ on pressure. The parameter $\alpha=c_{\text {exp }} / c_{\text {theor }}$ was obtained by normalizing the experimental values $c_{\exp }$ to calculated $c_{\text {theor }}[1,8]$ using the Stefan-Maxwell equations for a given geometry under the assumption of diffusion. As view of figure 1 a, for system $0,65 \mathrm{CH}_{4}(1)+0,35 \operatorname{Ar}(2)-\mathrm{N}_{2}$ (3) diffusion.

Experimental values of the concentrations of the components coincide with the calculated results within experimental error. Over the entire interval of the studied pressures, the parameter $\alpha \approx 1$. In the system $0,5538 \mathrm{H}_{2}(1)+0,4462 \mathrm{~N}_{2}(2)-\mathrm{CH}_{4}(3)$ is observed at a different picture in figure $1 \mathrm{~b}$. At a certain pressure $p^{*}$, the parameter $\alpha$ begins to significantly exceed unity. Starting with $p^{*}=1,07 M P a$ the parameter $\alpha_{i}$ increases for all components. Dependences, which shown in figure $1 \mathrm{~b}$ are not typical for diffusion, in which have to be decrease of the mixing intensity, in case, when increasing pressure. The priority transfer of the component with the highest molecular weight as compared to diffusion active hydrogen does not correspond to the generally accepted concept of diffusion mixing. Increasing the parameter $\alpha_{i}$ with increasing pressure indicates that convection occurs in the system due to the instability of the mechanical equilibrium of the gas mixture, and the pressure $\mathrm{p}^{*}$ determines the change in the regimes "diffusion - concentration gravitational convection".

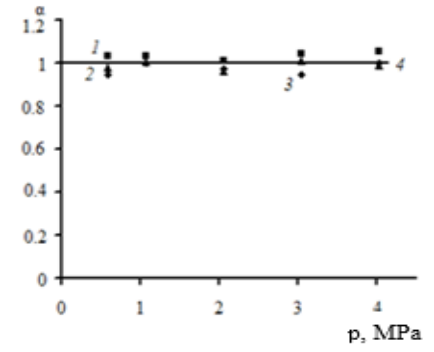

a

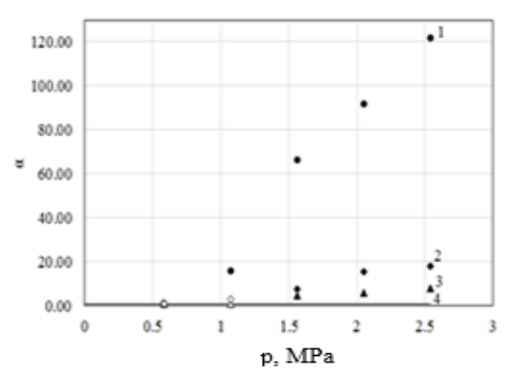

b

Figure 1. Dependence of the parameter $\alpha$ from pressure: a. $\mathrm{CH}_{4}+\mathrm{Ar}-\mathrm{N}_{2}, \mathrm{~T}=298,0 \mathrm{~K}$,

1 - methane, 2 - argon, 3 - nitrogen, 4 - calculation assuming diffusion; b. $\mathrm{H}_{2}+\mathrm{N}_{2}-\mathrm{CH}_{4}, 1$ - nitrogen, 2 - methane, 3 - hydrogen, 4 - calculation taking into account diffusion 
The occurring convective flows in figure 1 distort the transfer expected during diffusion. Intensity of convective mixing is also influence content of the component with the highest molecular weight in the initial mixture. If content of the component decreases, intensity of convective mixing decreases, consequently at a certain initial content only diffusion takes place.

For describe behavior of the gas mixture, we use the equations of free concentration convection in the Boussinesq approximation $[6,7]$ and assumption that $c_{i}$ and $p$ are represented as a sum of some average constants (hereinafter taken as the reference point) and small convective perturbations $c_{i}^{\prime}, p^{\prime}$, which do not lead to a significant deviation of the density $\rho^{\prime}$ from the average value $\rho_{0}$, that is

$$
c_{i}=\left\langle c_{i}\right\rangle+c_{i}^{\prime}, p=\langle p\rangle+p^{\prime}
$$

In dimensionless form, the system of perturbed convective equations can be written as follows (primes are omitted) [9]:

$$
\begin{gathered}
\operatorname{Pr}_{22} \frac{\partial c_{1}}{\partial t}-(\boldsymbol{v} \boldsymbol{\gamma})=\tau_{11} \nabla^{2} c_{1}+\frac{A_{2}}{A_{1}} \tau_{12} \nabla^{2} c_{2}, \\
\operatorname{Pr}_{22} \frac{\partial c_{2}}{\partial t}-(\boldsymbol{v} \boldsymbol{\gamma})=\frac{A_{1}}{A_{2}} \tau_{21} \nabla^{2} c_{1}+\nabla^{2} c_{2}, \\
\frac{\partial \boldsymbol{u}}{\partial t}=-\nabla p+\nabla^{2} \boldsymbol{u}+\left(R a_{1} \tau_{11} c_{1}+R a_{2} c_{2}\right) \boldsymbol{\gamma}, \\
d i v \boldsymbol{v}=0,
\end{gathered}
$$

Equations (1) contain the following parameters: $\operatorname{Pr}_{i i}=\frac{v}{D_{i i}^{*}}$ - Prandtl number, $R a_{i i}=\frac{g \beta_{i} A_{i} d^{4}}{v D_{i i}^{*}}-$ Rayleigh number, $\tau_{i j}=\frac{D_{i j}^{*}}{D_{22}^{*}}$ - complex that determines the ratio between multicomponent diffusion coefficients.

For solve the system of equations (1), it is necessary to concretize geometry of the problem, initial and boundary conditions. Solution of the problem multicomponent mixing in a cylindrical vertical channel of finite height with solid and impermeable boundaries for the substance made it possible to determine the concentration distribution along length in the form:

$$
\begin{gathered}
c_{i}=\frac{11 K_{i}\left(h^{2}-z^{2}\right)\left(5 h^{2}-z^{2}\right) \cos n \varphi}{248 \alpha^{2}\left(k^{2}+\alpha^{2}\right)} \times \\
\times\left[\begin{array}{l}
\alpha^{2} \frac{J_{n}(k r)}{J_{n}(k)}+ \\
+\frac{I_{n}(\alpha r)}{\alpha I_{n}(\alpha)}\left\{n\left(\alpha^{2}+k^{2}\right)-\alpha^{2} k \frac{J_{n}^{\prime}(k)}{J_{n}(k)}\right\} \\
-\left(k^{2}+\alpha^{2}\right) r^{n}
\end{array}\right]
\end{gathered}
$$

where $K_{i}$ - the numerical complexes, which depending on the initial composition and the coefficients of multicomponent diffusion, $I_{n}, J_{n}$ - the Bessel functions. Combining (1), (2) we obtain the stability boundary of considered problem

$$
\int \boldsymbol{u} \nabla^{2} \boldsymbol{u} d V+R a_{1} \tau_{11} \int u_{z} c_{1} d V+R a_{2} \int u_{z} c_{2} d V=0
$$


In figure 2 shows the neutral line (3) on the plane $R a_{1}, R a_{2}$ for the system $0,5538 \mathrm{H}_{2}(1)+0,4462 \mathrm{~N}_{2}(2)-\mathrm{CH}_{4}(3)$. Above line I, there is a convection area, and below - a diffusion area. For the most dangerous mode from the point of view of stability, the critical Rayleigh concentration numbers have the following values: $R a_{1}=64,6459, R a_{2}=49,8018$.

Line II which is shown in figure 2 corresponds to zero density gradient. Relative position of these lines shows the existence of the area (the sector between lines I and II in figure 2, when convection takes place in the system, although density in the upper part of the channel is less than in the lower channel, which, at first view, corresponds only to diffusion process. For the comparing results by determine the areas of diffusion and instability, we present the experimental data, under specified conditions, on the plane $R a_{1}, R a_{2}$ in the form of partial Rayleigh numbers. From experience it is determined, which regime (diffusion or convection) takes place. The points corresponding to the unstable regime will be denoted by signs $\bullet$, and the diffusion process will be corresponded to the $\circ$ signs, which shown in figure 2 .

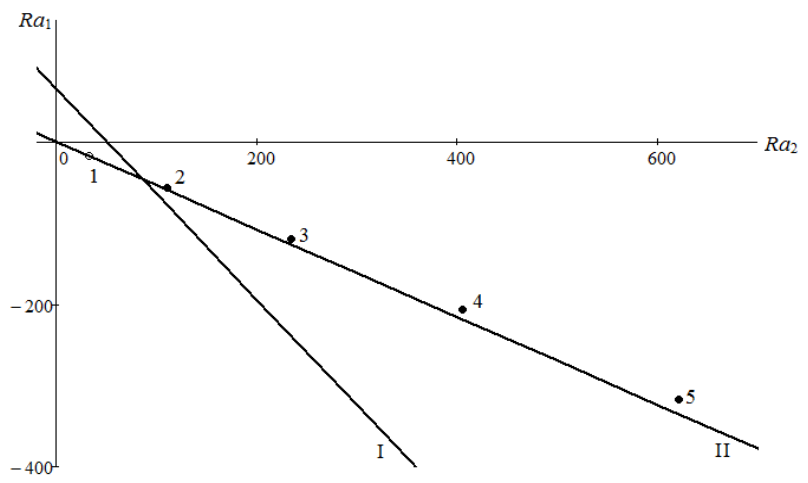

Figure 2. Areas of diffusion and convection:

I - perturbance boundary; II - line of zero density gradient; points 1 - 5 - experimental data at different values of p: 1 - 0.58, 2 - 1.07, 3 - 1.56, 4 - 2.05, 5 - 2.54 MPa.

The aggregate of such points on the plane of Rayleigh numbers determines the transition from diffusion area to convective area through the neutral stability line. Point 1 corresponds to diffusion. Points $2-5$ characterize the unstable regime. It is easy to see, that occurs satisfactory agreement between theory and experiment on the location areas of diffusion and concentration convection.

In three-component systems contains methane, where diffusion coefficients differ from each other, at certain values of pressure the mechanical equilibrium in mixture is violated. Transition from the diffusion regime to the convective is observed in the system. In terms of Rayleigh numbers, a boundary relation is obtained, that determines transformation of various types of mixing. Satisfactory agreement is noted between the experimental and calculated data on the location of the instability boundaries in the gas mixtures under research.

\section{Acknowledgments}

The work has been performed under the support of grant of Abai Kazakh National Pedagogical University (Grant No.03-05/360).

\section{References:}

1 Taylor, R. and Krishna R.: Multicomponent mass transfer - New York: John Wiley \&Sons, Inc., 1993.

2 Жаврин Ю.И., Косов В.Н., Кульжанов Д.У., Федоренко О.В. Экспериментальные методы исследования диффузии и концентрационной гравитачионной конвекции, вызванной неустойчивостью механического равновесия в многокомпонентных газовых смесях. - Алматы: Қазақ университеті, 2015. - C.172 - монография

3 Kosov V.N., Seleznev V.D., Zhavrin Yu.I. Separation of components during isothermal mixing of ternary gas systems under free convection conditions. Technical Physics. 1997; 42:p.1236-1237.

4 Dil'man V.V., Lipatov D.A., Lotkhov V.A., Kaminskii V.A. Instability in unsteady-state evaporation of binary solutions into an inert gas. Theoretical Foundations of Chemical Engineering 2005; 39: p.566-572.

5 Kosov V.N. Fedorenko, O.V., Zhavrin, Yu.I., Mukamedenkyzy V. Instability of mechanical equilibrium during diffusion in a three-component gas mixture in a vertical cylinder with a circular cross section. Technical Physics, 2014; 59. p. 482-486.

6 Joseph D.D.: Stability of fluid motions. Berlin Heidelberg-New York: Springer-Verlag, 1976. 
7 Nield D.A., Bejan, A.: Convection in Pores Media. Springer, New York, 3rd edition, 2006.

8 Bird R.B., Stewart W.E., Lightfoot E.N. Transport Phenomena. New York: John Wiley \& Sons, Inc., 2nd Edition, 2002.

9 Kossov V., Krasikov S., Fedorenko O. Diffusion and convective instability in multicomponent gas mixtures at different pressures. Eur. Phys. J. Special Topics, 2017;226: p.1177-1187.

\section{References}

1 Taylor, R. and Krishna R. (1993) Multicomponent mass transfer. New York: John Wiley \&Sons, Inc. (In English)

2 Zhavrin Ju.I., Kosov V.N., Kul'zhanov D.U., Fedorenko O.V. (2015) Jeksperimental'nye metody issledovanija diffuzii $i$ koncentracionnoj gravitacionnoj konvekcii, vyzvannoj neustojchivost'ju mehanicheskogo ravnovesija $v$ mnogokomponentnyh gazovyh smesjah [Experimental methods for studying diffusion and concentration gravity convection caused by instability of mechanical equilibrium in multicomponent gas mixtures]. Almaty, Kazak universiteti. 172, monografija. (In Russian)

3 Kosov V.N., Seleznev V.D., Zhavrin Yu.I. (1997) Separation of components during isothermal mixing of ternary gas systems under free convection conditions. Technical Physics. 42. 1236-1237. (In English)

4 Dil'man V.V., Lipatov D.A., Lotkhov V.A., Kaminskii V.A. (2005) Instability in unsteady-state evaporation of binary solutions into an inert gas. Theoretical Foundations of Chemical Engineering. 39, 566-572. (In English)

5 Kosov V.N. Fedorenko, O.V., Zhavrin, Yu.I., Mukamedenkyzy V. (2014) Instability of mechanical equilibrium during diffusion in a three-component gas mixture in a vertical cylinder with a circular cross section. Technical Physics. 59. 482-486. (In English)

6 Joseph D.D. (1976) Stability of fluid motions. Berlin Heidelberg, New York: Springer-Verlag. (In English)

7 Nield D.A., Bejan, A. (2006) Convection in Pores Media. Springer, New York, 3rd edition. (In English)

8 Bird R.B., Stewart W.E., Lightfoot E.N. (2002) Transport Phenomena. New York, John Wiley \& Sons, Inc., 2nd Edition. (In English)

9 Kossov V., Krasikov S., Fedorenko O. (2017) Diffusion and convective instability in multicomponent gas mixtures at different pressures. Eur. Phys. J. Special Topics, 226. 1177-1187. (In English) 